\title{
FIELD NOTES ON SYRIAC MANUSCRIPTS I: TWO MEDICAL MANUSCRIPTS DIGITIZED BY THE HILL MUSEUM \& MANUSCRIPT LIBRARY
}

\author{
GRIGORY KESSEL \\ AUSTRIAN ACADEMY OF SCIENCES \& UNIVERSITY OF \\ MANCHESTER
}

\begin{abstract}
This first installment in a series of articles on Syriac manuscripts offers a concise description of two previously unknown manuscripts kept in two small collections in Iraq. Both manuscripts are exclusively of medical content and offer new copies of already known medical works, such as Questions on Medicine for Students by Hunain $b$. Ishaqq and the Syriac Book of Medicines. The two manuscripts are notable not only as new manuscript witnesses but also because they allow us to understand better the manuscript transmission of the texts they contain. Thus, they turn out to be the direct models of two manuscripts of the same content held in European collections (Mingana Syr. 594 and BNF Syr. 425-425).
\end{abstract}


In the course of my research I regularly deal with a large number of Syriac manuscripts. I study some of these in situ in various libraries around the world, whereas I access others in digital form. Inevitably, I come across not only previously unknown (or little known and not previously accessible) manuscript witnesses to a given Syriac text but also although much less often - unique copies for texts never known before. Finally, sometimes it is not the text but its carrier, the manuscript, that is worthy of special attention. It goes without saying that I try to retain all the noteworthy manuscripts, hoping to put my hands on them sooner or later. As the list grows, so also does my recognition of the unfeasibility of such a task. This is why I decided to launch a series of articles where I will briefly present manuscripts that are worthy of additional scholarly attention. Many of those come from the digital holdings of the Hill Museum \& Manuscript Library (Collegeville, MN) and are already (or will be) catalogued for the online catalogue. Although the records for some of the manuscripts may be already available online, I find it productive to produce new descriptions, lest the texts remain unnoticed.

The two manuscripts selected for the initial issue are rare specimens of non-religious manuscripts, particularly on the subject of medicine. All the manuscripts presented below belong to the little known small collections in Iraq, and I was able to find them during a perusal of digital holdings of HMML during my visit in October 2016. ${ }^{1}$

The research leading to this article received funding from the European Research Council under the European Union's Seventh Framework Programme (FP7/2007-2013) / ERC Grant Agreement n. 679083 as part of the research project 'Transmission of Classical Scientific and Philosophical Literature from Greek into Syriac and Arabic' (HUNAYNNET), carried out at the Austrian Academy of Sciences.

${ }^{1}$ I would like to express my appreciation to the HMML, its director Fr. Columba Stewart, and staff for arranging the visit. 


\section{BAGHDAD, PRIVATE COLLECTION OF BISHOP JĀK ISḤAQ}

\section{BJI 13. Medical Miscellany}

September 21, $1921 \mathrm{CE}$ [2232 AG]

Alqōsh

Paper

132 fols.

Layout varies (1 or 2 columns; $29-34$ lines per page). $35,5 \times 25,5 \times 3,5 \mathrm{~cm}$

East Syriac handwriting with vocalization

Modern foliation in Arabic numerals in the upper left corner

CONDITION: complete

CATALOGUE DESCRIPTION: -

HISTORY: From the colophon (f. 128r) we learn that the manuscript was produced by three scribes: a prolific Chaldean scribe Elìyā Hōmō (1856-1932; introduced in the manuscript as follows: 'priest Elìyā Hōmō, son of deacon Hōmō, son of deacon Isha'yā, son of priest Hōmō, son of priest Hannā, son of priest Hōmō, son of priest Daniel, son of priest Elìyā, son of priest Daniel, son of priest Elìyā, of Nașrō family of Alqōsh') and his two sons, deacon Yawsep (1893-1975) and a student or a priest in training (eskōolàya ) Hannā. ${ }^{2}$ Elìyā Hōmō copied the first quire and a half of the second; Yawsep continued up till the end of the tenth quire, and Hannā completed the copying. Interestingly, whereas the change of hand between Yawsep and Hannā is easily noticeable, that between Elìyā Hōmō and Yawsep is not and it may have to do with Hannā's lack of professional training.

\section{CONTENTS:}

General title of the volume (but may in fact belong exclusively to the first text):

${ }^{2}$ On Elìyā Hōmō and his sons see in D. Wilmshurst, The Eccesiastical Organisation of the Church of the East, 1318-1913, CSCO, Subsidia 104 (Louvain: Peeters, 2000), 254 and 'Immānū'îl Mūsā Shikwānā, Hatțațūn mašāriqa (Dohūk: Dār al-mašriq al-țaqāfiyah, 2007), 22, 76, 84. 


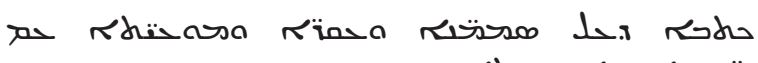 \\ кमمeora räi}

'Volume [or: book] about drugs, roots, plants, seeds and healing'.

1. ff. $5 \mathrm{r}-23 \mathrm{r}$

Author: anonymous

Title:

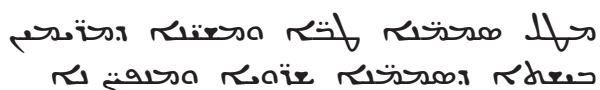

'On beneficial and soothing drugs that deaden the harm of the laxative and purgative drugs'.

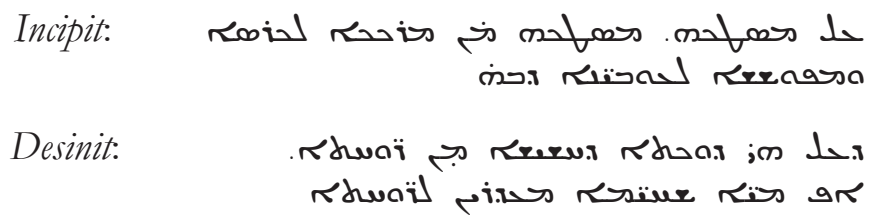

$E$ d: the text is unedited but has been explored in a number of studies of Ph. Gignoux.

Lit::

Gignoux, Ph. "Le traité syriaque anonyme sur les medications." In Symposium Syriacum VII: Uppsala University, Department of Asian and African Languages, 11-14 August 1996, Orientalia Christiana Analecta 256, ed. R. Lavenant. Rome: Pontificium Institutum Orientalium Studiorum, 1998, 725733.

Gignoux, Ph. "On the Syriac Pharmocopoeia." The Harp 11-12 (1998-1999): 193-201.

Gignoux, Ph. "Les relations interlinguistiques de quelques termes de la pharmacopée antique." In Literarische Stoffe und ibre Gestaltung in mitteliranischer Zeit: Kolloquium anlässlich des 70. Geburtstages von Werner Sundermann, Beiträge zur Iranistik 31, ed. D. Durkin-Meisterernst, C. Reck and D. Weber. Wiesbaden: Harrassowitz, 2009, 91-98.

Gignoux, Ph. "Les relations interlinguistiques de quelques termes de la pharmacopée antique, II." In Exegisti monumenta: Festschrift in bonour of Nicholas Sims-Williams, Iranica 17, ed. W. Sundermann, A. Hintze and F. de Blois. 
Wiesbaden: Harrassowitz, 2009, 117-126.

Gignoux, Ph. "La pharmacopée syriaque exploitée d'un point de vue linguistique.” Le Muséon 124.1-2 (2011): 11-26.

2. ff. $25 \mathrm{r}-66 \mathrm{r}$

Author: [Hunain b. Ishāā]

Title:

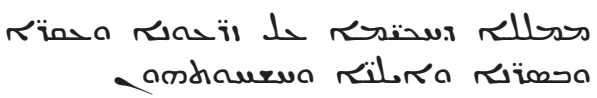

'Treatise [based on the works] of the wise about the herbs, roots, animals, trees and their usefulness'

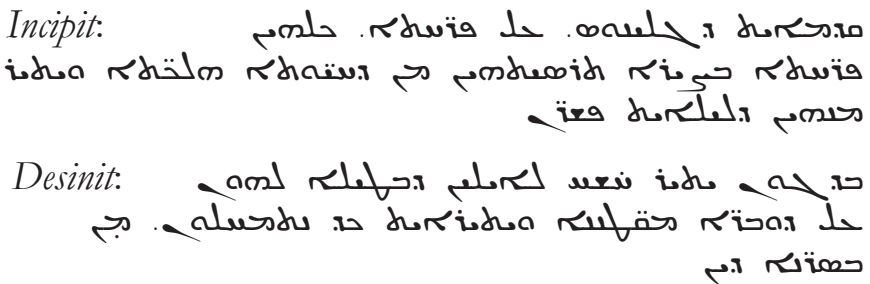

Ed.: the edition of the text is in preparation by R. Hawley (Paris) as a part of ERC Project FLORIENTAL.

Lit:

Degen, R. "A Further Note on Some Syriac Manuscripts in the Mingana Collection." Journal of Semitic Studies 17:2 (1972): 213-217.

Hawley, R. "Preliminary Notes on a Syriac Treatise about the Medicinal Properties of Foodstuffs." Semitica et Classica 1 (2008): 81-104.

Hawley, R. "Three Fragments of Antyllus in Syriac Translation". In Sur les pas des Araméens chrétiens. Mélanges offerts à Alain Desreumaux, ed. F. Briquel-Chatonnet and M. Debié. Paris: Geuthner, 2010, 241-256.

3. ff. $67 \mathrm{r}-72 \mathrm{v}$

Author: Ahūdemmēh Anțīpațrōs

Title:

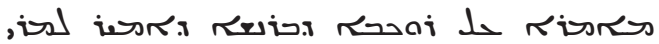

$$
\begin{aligned}
& \text { coifa.tr msरx mंnर }
\end{aligned}
$$


'Mèmrā on the composition of man'

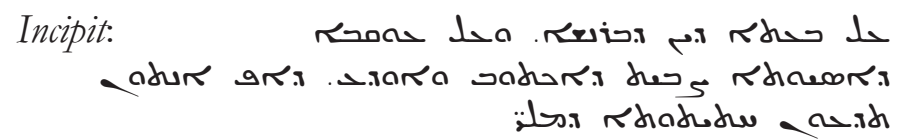

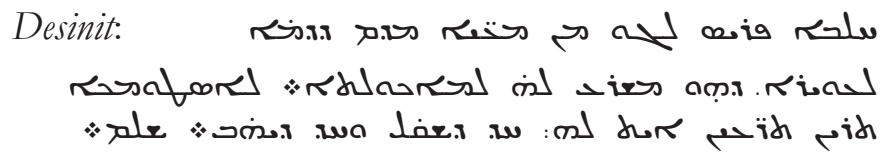

Ed:

Chabot, J.B. "Notice sur deux manuscrits contenant les œuvres du moine Isaac de Rabban Isho et du métropolitain Ahoudemmeh." Notices et extraits des manuscrits de la Bibliothèque Nationale et autres bibliothèques XLIII (1943): 4376, here 53-60.

Lit:

Gignoux, Ph. "Anatomie et physiologie humaine chez un auteur syriaque, Ahūhdemmeh." Comptes-rendus des séances de l'année de l'Académie des inscriptions et belles-lettres 1998, 231-242.

Reinink, G.J. "Man as Microcosm: a Syriac Didactic Poem and Its Prose Background." In Calliope's Classroom. Studies in Didactic Poetry from Antiquity to the Renaissance, ed. A. Harder, A.A. MacDonald and G.J. Reinink. Leuven: Peeters, 2007, 123-152.

The identity of the author is uncertain. According to Chabot, the text may go back to the lost Greek original, whereas Gignoux identifies him with Ahūdemmēh, the bishop of Nineveh, who attended the synod of Catholicos Joseph I in 554 (for Gignoux he also authored another treatise, edited by F. Nau in Patrologia Orientalis 3,1). Finally, Reinink considers the text as a translation made from the Greek.

4. ff. $72 \mathrm{v}-74 \mathrm{v}$

Author: anonymous

Title:

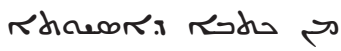

'From the Book of Medicine' 


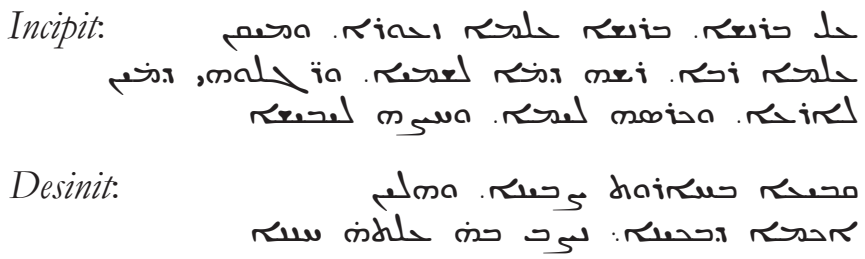

Ed:

Chabot, J.B. "Notice sur deux manuscrits contenant les œuvres du moine Isaac de Rabban Isho et du métropolitain Ahoudemmeh." Notices et extraits des manuscrits de la Bibliothèque Nationale et autres bibliothèques XIIII (1943) 43-76, here 60-63.

Lit::

Gignoux, Ph. "Anatomie et physiologie humaine chez un auteur syriaque, Ahūhdemmeh." Comptes-rendus des séances de l'année de l'Académie des inscriptions et belles-lettres 1998, 231-242.

Reinink, G.J. "Man as Microcosm: a Syriac Didactic Poem and Its Prose Background." In Calliope's Classroom. Studies in Didactic Poetry from Antiquity to the Renaissance, ed. A. Harder, A.A. MacDonald and G.J. Reinink. Leuven: Peeters, 2007, 123-152.

Kessel, G. 2011. "La position de Simon de Taibuteh dans l'éventail de la tradition mystique syriaque." In Les mystiques syriaques, Études syriaques 8, ed. A. Desreumaux. Paris: Geuthner, 2011, 121-150.

The text is transmitted in two different forms: independently and in combination with the preceding one. For Chabot, it is related to the original works by Ahūdemmēh, who was identified by him as a Syrian Orthodox Metropolitan. Gignoux argued that all three texts (the two preserved in the manuscript and the one edited by Nau) were produced by the East Syriac bishop of Nineveh who attended the synod of Catholicos Joseph I in 554. On the contrary, Reinink suggested that the text cannot be attributed to the same author who produced the text edited by Nau. I had a chance to present my position on the issue, namely that the text comes from the Book of Medicine 
by Šem`ōn d-Ṭaibūtēh and hope to offer more detailed examination before too long.

5. ff. $74 \mathrm{v}-113 \mathrm{v}$

Author. Hunain b. Isḥāq, Hubaysh b. al-Hasan alDimashqī

Title:

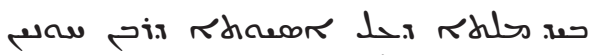

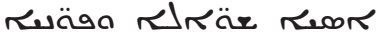

'Treatise about medicine in questions and answers'

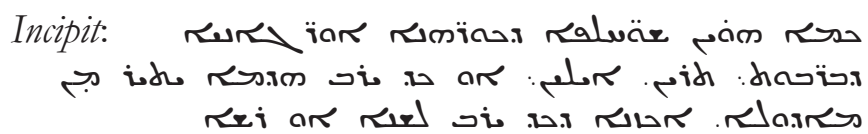

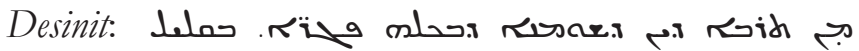

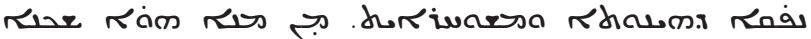

dosis

The text is incomplete and its end corresponds to p. 594 line 9 of Wilson/Dinkha's edition.

Ed:: Chabot, J.-B. "Version syriaque de traités médicaux don't l'original arabe n'a pas été retrouvé." Notices et extraits des manuscrits de la Bibliothèque Nationale et autres bibliothèques XLIII (1943): 77-143.

Wilson, E.J., Dinkha, S., Hunayn Ibn Ishaq's "Questions on Medicine for Students". Transcription and Translation of the Oldest Extant Syriac Version (Vat. Syr. 192), Studi e testi 459, Città del Vaticano: Biblioteca Apostolica Vaticana, 2010 (see also the review by the present author in Hugoye: Journal of Syriac Studies 15:2 (2012): 367-392).

Edition of Wilson/Dinkha is based on one (though the oldest) manuscript that is damaged at beginning. Chabot relied on a different (a modern copy, CSCO syr. 21) manuscript that preserves the missing part.

6. ff. $119 \mathrm{r}-128 \mathrm{r}$

Author: anonymous 


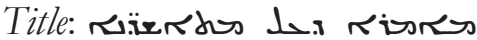

'Mèmrā on humours'

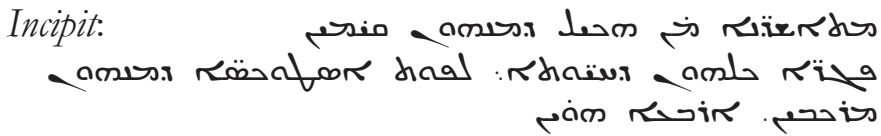

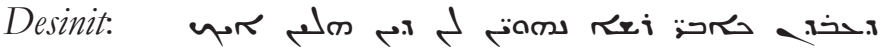

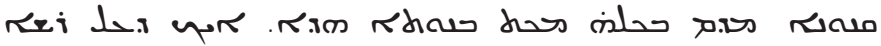

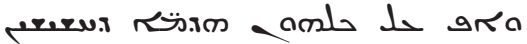

$E d$ : the text remains unedited.

As found by Degen, the text has some material in common with the Book of Medicines. Among the authorities mentioned in the work features the names of Hnānīshō' Bar Sārōshway, bishop of Hīirtā, Ahūdemmēh Anțipațros, Hunayn, Bar 'Ebrōyō, Hippocrates, Diocles, Archigenes.

Lit::

Degen, R. "A Further Note on Some Syriac Manuscripts in the Mingana Collection." Journal of Semitic Studies 17:2 (1972): 213-217.

NOTES: The texts preserved in the manuscript are attested also in other copies. The scribe, Elìyā Hōmō is known to have produced two manuscripts of similar content, one in 1901 (BNF syr. 21) and another in 1904 (CSCO syr. 21). The former contains texts 1, 2 and an additional piece. The latter provides the same texts (though in a slightly different order) as BJI 13 and a couple of additional pieces. Manuscript CSCO syr. 21 was produced upon request of JacquesEugène Manna for Jean-Baptiste Chabot and was used by the latter for an edition of the texts by Ahūdemmèh and Hunayn and later formed part of the so-called CSCO collection of Syriac manuscripts. That collection was described by André de Halleux 
but its present location is unfortunately unknown. ${ }^{3}$ There is however one more manuscript, this time of precisely identical content, namely Mingana syr. 594. According to its colophon (Mingana syr. 594, ff.174r175r), it is dated to October 31, 1932 and was copied in Alqōsh by the deacon Yawsep, yet another prolific Chaldean scribe of the period. The copy was commissioned by the famous Syriac Orthodox scribe Matthew bar Paulos on behalf of A. Mingana. Importantly enough, the scribe informs us that the original manuscript was copied by the priest Eliya Hōmō in Alqosh in 21 September 1921. Now, while comparing the available information about the two manuscripts it becomes clear that it was the manuscript BJI 13 that served as a direct model for the production of Mingana syr. 594.

\section{Telkepe, Church of THE SaCred Heart}

\section{QACCT 00149. Syriac Book of Medicines}

Paper

186 fols.

2 cols., 37 lines per page

$31 \times 21 \times 6 \mathrm{~cm}$

East Syriac handwriting with vocalization

Modern foliation in Hindu-Arabic numerals in the upper left corner ${ }^{4}$

CONDITION: The manuscript is damaged (VIII-1, IX-6, XVIII-3, XX-4), particularly the final part is missing. The exact number of missing quires is impossible to ascertain. Ff. 187-194 are all disjointed loose leaves. Present f. 189 belongs to quire XVI.

3 A. De Halleux, "Les manuscrits syriaques du 'CSCO'." Le Muséon 100 (1987): 35-48.

4 The foliation differs from that supplied during digitisation by one (e.g. f. $5 r=6 r)$. 
CatAlogue DesCription: ${ }^{5}$ Habbī, Y. "Makhțūțāt kanīsat Telkayf." In Fahäris al-makehtūtā al-suryāniyyah fì al-'Irāq, vol. 1. Baghdad, 1981, 21-49, here 45 (number 86) ${ }^{6}$. A provisional entry is available at the online catalogue of HMML.

HistORY: According to the colophon (f. 144v), the manuscript was completed in Alqōsh on May 11, 1803 [2114 AG] by Gabriel, son of the priest Khāwshābāa, a prolific Chaldean scribe. ${ }^{7}$ Elsewhere in the manuscript (f. 192r) Gabriel records the year 2114 AG [1802/3 CE]. According to Gabriel, he copied the manuscript for himself (nor

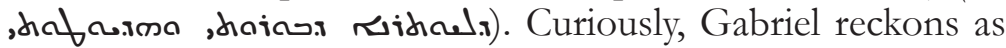
the current patriarch Yōhanannān, who should be identified with Yōhannān VIII Hormizd, the first in the Mosul (united) line of the Chaldean Patriarchate. The period between 1780 when he was elected as a patriarch but was not recognized by the Vatican until 1830 was fueled with rivalry for the patriarchal see. ${ }^{8}$ Apparently, the scribe Gabriel from Alqōsh was his faithful supporter, for he did not fail to reckon him as a patriarch in the manuscripts' colophons from the year 1803 (Mingana syr. 94) onwards. A note on f. $2 \mathrm{r}$ informs us that the manuscript was sold to the church of Mar Quriāqōs in Telkepe.

Contents:

1. ff. $2 \mathrm{v}-144 \mathrm{v}$

Book of medicines. Therapeutic section.

5 On that collection see also a survey in Kh. Foumia, "The Manuscripts of the Church of Telkeppe." Journal of the Canadian Society of Syriac Studies 13 (2013): 66-76. The author has prepared a catalogue of the collection but to the best of my knowledge it has not been published yet.

${ }^{6}$ The catalogue offers a succinct description of manuscript's content as a 'medical book'.

7 On him see in Wilmshurst, The Eccesiastical Organisation, 252, Shikwānā, Hațtạțūn mašăriqa, 46-47.

8 See Wilmshurst, The Eccesiastical Organisation, 26-32. 


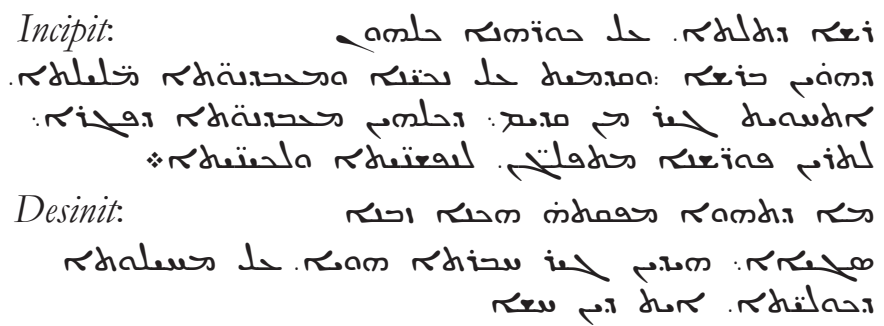

Ed.: Budge, E.A.W. (ed. and trans.), Syrian Anatomy, Pathology and Therapentics, or 'The Book of Medicines': The Syriac Text, Edited from a Rare Manuscript, with an English Translation. 2 vols. New York: Oxford University Press, 1913. Vol. 2, 1-441.

2. ff. $145 \mathrm{r}-194 \mathrm{v}$

Book of medicines. Astrological section and recipes.

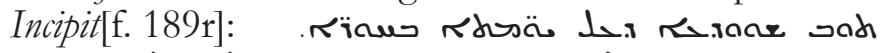

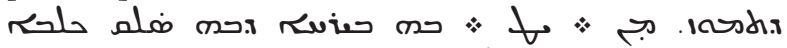

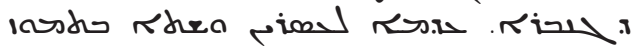

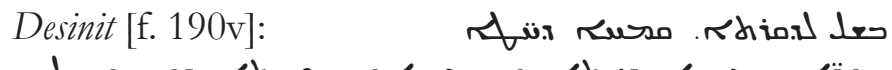
 כמקr

Ed:: Budge, Syrian Anatomy, Pathology, 441 - 576.

NOTES: The final part of the manuscript is severely damaged with just some remaining loose folios. It is not possible to estimate with certainty how much of the text is lost but it is likely that in its original form the manuscript covered the whole astrological section as well as the folk-medicine recipes. The astrological section differs from that edited by Budge and contains new texts. Some texts that are missing in Budge's edition are attested elsewhere. For example, a piece on augury on ff. $192 \mathrm{r}-194 \mathrm{r}$ is similar to the text preserved in the British Library Or. 2084, which was 
edited by Furlani. ${ }^{9}$ The manuscript QACCT 149, however, presents a more extensive version of the text. It is possible to identify some texts on the loose leaves: ff. $184-186=$ p. 555 line $13-564$ line 9, f. 190 $=$ p. 573 line $5-576$ line 5 .

The manuscript contains the so-called Syriac Book of Medicines edited by E.A.W. Budge. The text is famous for the variety of its content. On the one hand, we find there a scholarly medical encyclopedia that is based on the works of Galen; on the other hand, it contains also a large number of astrological pieces as well as prescriptions and recipes that stem from folk-medicine. Despite the intense interest in this treatise by historians of medicine, it has not been studied properly by Syriac scholars. Moreover, Budge's diplomatic edition, which is based on a single manuscript, remains our only available source despite the fact that there are other extant manuscript copies, some of which are significantly older than the manuscript produced at Budge's request. To the latter ones we can add now also the manuscript QACCT 149.

It is highly likely that the manuscript QACCT 149 served as one of the models for another copy of the Book of Medicines, namely Bibliothèque Nationale de France, syr. 424-425. ${ }^{10}$ That copy was produced in two volumes and, thanks to the informative colophon of its scribe, we know about the manuscripts that he used. BNF syr. 424-425 was produced by a previously

9 G. Furlani, "Due trattati palmomantici in siriaco." Rendiconti della Reale Accademia Nazionale dei Lincei. Classe di scienze morali, storiche e filologiche V, 26 (1917): 719-732, here 723-725.

10 For detailed description see F. Briquel-Chatonnet, Manuscrits syriaques de la Bibliothèque nationale de France ( $n^{o s} 356-435$, entrés depuis 1911). Catalogue (Paris, Bibliothèque nationale de France, 1997), 164-166. The two-volume manuscript is now available at <http://gallica.bnf.fr/ark:/ 12148/btv1b105263199> and <http://gallica.bnf.fr/ark:/12148/ btv1b10526322k>. 
mentioned scribe, Elīyā Hōmō, in 1900 in Alqōsh. Elīyā Hōmō relates that he used two manuscripts: one of the year 1699 copied by his great grandfather, priest Hōmō for the therapeutic part; due to the defective condition of the first, the remaining part was taken from a second manuscript, copied by the deacon Gabriel, son of the priest Hadbshabbā from Alqōsh dated to August 18, 1805. It is thus tempting to imagine that the second manuscript used by Eliya Hōmō was QACCT 149. Indeed, a quick comparison of QACCT 149 and BNF syr. 424-425 strongly supports such an assumption. The only difference is that, according to Elìyā Hōmō, his model was copied in 1805, whereas QACCT 149 is dated to the year 1803. Unless we admit that the scribe Gabriel produced more than one copy of the same text soon after the first one, one should consider that for some reason it took him two years to complete the copying. A certain slowness is well understandable if Gabriel was indeed copying the manuscript for his own interest. Work on other manuscripts must have taken most of his time. For example, we are aware that during the same period of 1803-1805 he produced at least two other manuscripts, Mingana syr. 94 and Vat. syr. 469. However, given the fact that exactly the same

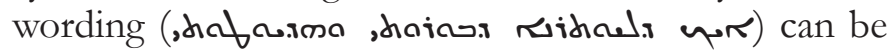
found in other manuscripts produced by Gabriel (e.g. Vat. syr. 469, Chaldean Church in Alqosh 45), it may be considered as belonging to the stock of formulaic expressions. ${ }^{11}$

${ }^{11}$ See now Th. Carlson, "Formulaic Prose? Rhetoric and meaning in Late Medieval Syriac Manuscript Colophons." Hugoye: Journal of Syriac Studies 18.2 (2015): 379-398 and H.L. Murre-van den Berg, Scribes and Scriptures. The Church of the East in the Eastern Ottoman Provinces (1500-1850), Eastern Christian Studies 21 (Leuven: Peeters, 2015), 113-142. 


\section{IMAGES}

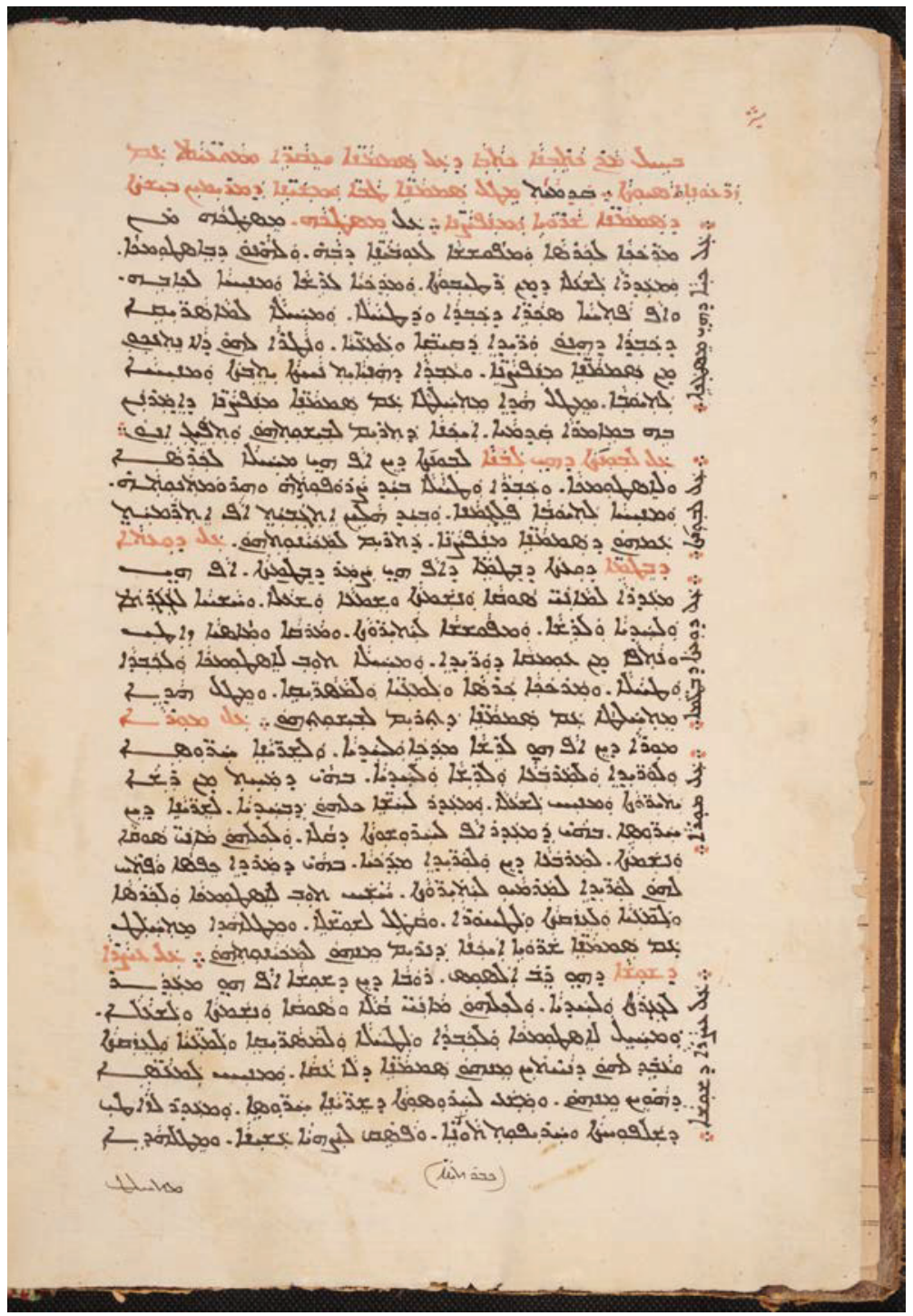

\section{Plate 1. BJI 00013, fol. 5v}

Published with the permission of Bishop Jāk Ishaq. The images are supplied by the Hill Museum \& Manuscript Library. 


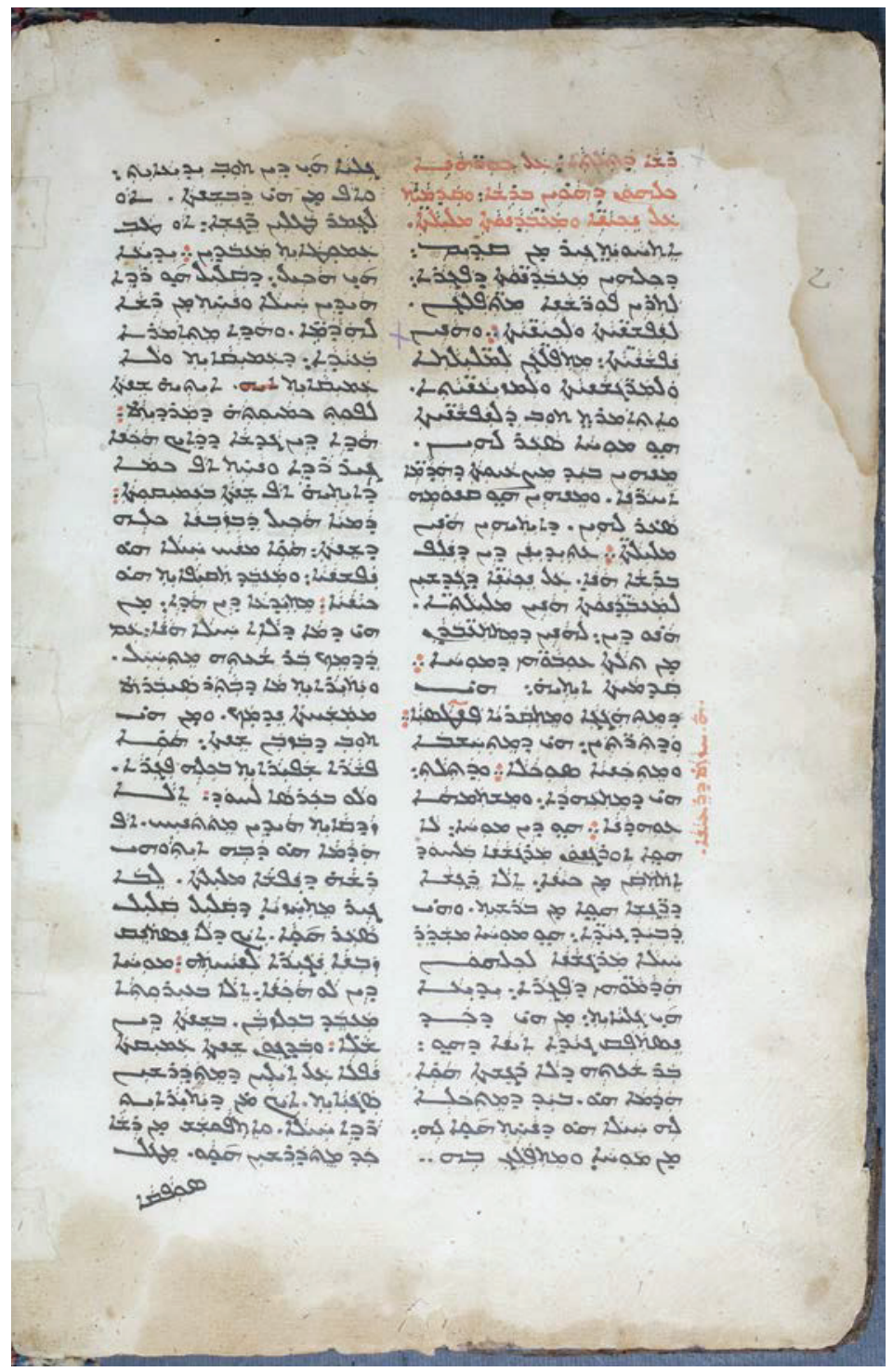

Plate 2. QACCT 00149, fol. 2v

Published with the permission of the Church of the Sacred Heart, Telkepe.

The images are supplied by the Hill Museum \& Manuscript Library. 